correspond to optimal solutions, in which the cells live longer than in any other.

The investigations just alluded to have proved that de Vries' constant isotonic coefficients, excellent as they are for a first approximation, are not sufficiently exact for more minute experiments. Here it is advisable to use, instead of them, the coefficients of electric conductivity, which vary slightly with the concentration of the solution.

Thus, osmotic pressures are not strictly proportional to the concentration of the plasmolysing solutions, and these pressures ought no more to be expressed in molecule-grams of $\mathrm{NO}_{3} \mathrm{~K}$, as is now generally done. The use of an atmosphere as unit, though better, is also objectionable, as it varies from one place to another.

I would therefore suggest to adopt the C.G.S. unit of pressure, viz. I dyne per sq. cm., or rather (to avoid useless decimals) I myriadyne per $s q . \mathrm{cm}$., i. e. the pressure of 10,000 dynes per sq. cm., the dyne being the force which gives the mass of $\mathbf{I}$ gram in I second an acceleration of $\mathbf{I} \mathrm{cm}$. per second.

This unit is roughly equal to $\frac{1}{10} 0$ atmosphere; we found it to be very convenient for all sorts of osmotic calculations.

L. ERRERA, Brussels.

\title{
THE FORM OF THE PROTOPLASMIC BODY IN CERTAIN
}

FLORIDEAE.-In Ceramium rubrum and other species a strong strand of protoplasm runs along the axial cells from pit to pit. In this strand the nucleus is occasionally suspended; more often it lies over the pit at the base of the strand.

In Dasya coccinea the branches of limited growth run out into pointed uncorticated filaments, the cells of which are large. Across the vacuole of these cells, running from pit to pit, occurs a thread of protoplasm much more delicate than the corresponding structure in Ceramium.

In Callithamnion byssoides threads of protoplasm radiate from a cushion lying over the pit and end blindly on the vacuole. These threads are in incessant movement, swinging over, bending on themselves, and extending or retracting. All these phenomena point to the great physiological importance of the pit-communication between cell and cell.

University College, BAngor.

R. W. PHILLIPS.

\section{Q q 2}




\section{$2 \mathrm{BHL}$ Biodiversity Heritage Library}

Phillips, Reginald W. 1898. "The form of the protoplasmic body in certain Florideae." Annals of botany 12, 569-569. https://doi.org/10.1093/oxfordjournals.aob.a088717.

View This Item Online: https://www.biodiversitylibrary.org/item/233102

DOI: https://doi.org/10.1093/oxfordjournals.aob.a088717

Permalink: https://www.biodiversitylibrary.org/partpdf/318529

\section{Holding Institution}

Smithsonian Libraries

\section{Sponsored by}

Biodiversity Heritage Library

\section{Copyright \& Reuse}

Copyright Status: Not in copyright. The BHL knows of no copyright restrictions on this item.

This document was created from content at the Biodiversity Heritage Library, the world's largest open access digital library for biodiversity literature and archives. Visit BHL at https://www.biodiversitylibrary.org. 